\title{
The design of English situational teaching model in Vocational College with the help of media network
}

\author{
Jing Cui \\ Hainan Institute of Science and Technology, Haikou, Hainan Province, 571126, China
}

Keywords: Media Networks; Vocational English; Situational teaching method

\begin{abstract}
Under the situation teaching model, we can constantly optimize the students' living environment and integrate their cognition with the emotion through the creation of certain teaching situation. It is a scientific and humanized educational model to stimulate the students' enthusiasm for learning English and to achieve active learning and development of students. This paper discusses the design of English situational teaching mode in Vocational College with the help of educational network.
\end{abstract}

In recent years, our country has vigorously conducted a new round of basic education curriculum reform. In this process, the classroom teaching method has also been greatly reformed and innovated. A large number of new teaching methods have been continuously emerged, and are being actively applied to many different disciplines in classroom teaching. Among them, the situational teaching method is a very important teaching mode. In this teaching mode, we can create vivid and interesting situations in accordance with the content of the teaching materials, so that students can be infected with the scenes and their interest of learning and the desire for knowledge can be stimulated

\section{The Application Value of Situational Teaching Model in Vocational English Teaching}

English is a very important part of the higher education system. It is conducive to cultivating students' multi-faceted English proficiency, enhancing their comprehensive English proficiency and laying a good foundation for their future career development through conducting English teaching. However, in the past traditional mode of higher vocational English teaching, most of them adopt the method of teacher telling. Students are lack of interest and enthusiasm in learning, most of them can only learn all kinds of books' information mechanically. In this mode, the overall teaching efficiency and effectiveness are not satisfactory. Situational teaching mode refers to creating corresponding teaching situations for students during the teaching process, designing the teaching links for students, placing teaching contents and teaching process in teaching situations, and fully promoting students to enhance the ability of understanding the knowledge, so as to achieve the best teaching results. The use of situational teaching method is also directly related to the cultivation of students' autonomous ability in the new curriculum standard. It is one of the new teaching modes based on the new curriculum standard's teaching idea.

Under the situational teaching model, teachers can be targeted to simulate the corresponding situations in accordance with the specific content of English teaching and the actual situation in the classroom. Then they can effectively stimulate students' interest in learning, help students understand the text content and better grasp their knowledge, so as to improve students' learning efficiency and enhance teachers' teaching effect. In the current teaching process of the new curriculum, we attach great importance to the cultivation and promotion of students' learning abilities of autonomous and cooperative and encourage students to actively explore knowledge. While, the premise of all this is to give full attention to students. exploring the depth and breadth of students' participation and applying situational teaching method in Higher Vocational English teaching are conducive to creating a new situation in the classroom and realize the new teaching 
face that simplified the complex problems and interested the boring problems. The application pattern and process of the situational teaching method are shown in Table 1 . In the specific situation teaching, the visual and the hearing are combined together, the specific teaching content is used, the specific situation is taken as the center, gestures, pictures, slides, multimedia, courseware and other teaching aids are used to create scenarios to cultivate the students' listening and speaking ability and to promote their English comprehensive improvement. At the same time, the situation teaching method also provides a broader platform for exchange between educators and students. We can simulate and reproduce the English knowledge and skills and communication scenes in a specific period to learn the teaching contents in the classroom by setting certain teaching scenarios. So as to create a real, three-dimensional and vivid learning picture for the students. To better guide students through natural, real way. To help students to be immersed in the real atmosphere of English learning and application, and then thinking and learning. In the meantime, in the real situation, students can experience some situations and communicate with their classmates and teachers in the classroom. Through exchange, interaction, teachers can help students to better learn a variety of English knowledge and skills, and to promote effective improvement of the student's emotional system.

Table 1 application mode and process of situational teaching method

\begin{tabular}{|l|l|}
\hline Application process & contents \\
\hline $\begin{array}{l}\text { Inquisition before } \\
\text { class }\end{array}$ & Prepare and explore the teaching content before class. \\
\hline $\begin{array}{l}\text { Designing scenarios } \\
\text { and activities }\end{array}$ & Design a certain teaching situation with teaching content; \\
\hline Present a scene & Use multimedia to show the specific teaching situation. \\
\hline $\begin{array}{l}\text { The development of } \\
\text { Learning activities }\end{array}$ & $\begin{array}{l}\text { Complete a certain task of learning through the cooperation or } \\
\text { independent learning, thinking training, etc.,. }\end{array}$ \\
\hline
\end{tabular}

\section{The design of English situational teaching model in Vocational College with the aid of media network}

In vocational English teaching, taking into account the needs of the students' future career development, they often teach students some hotel related English knowledge and skills. In order to better improve students' comprehensive English proficiency and lay a good foundation for their future career development. In the research of this article, we analyze the application of English-related teaching activities in hotels in accordance with the related processes of scenario teaching method mentioned above. The following links are included in the concrete teaching.

\subsection{Inquisition before class}

Before teaching in the classroom, we should first guide the students to carefully read the contents of the textbooks. On the basis of the preliminary mastery of the general content of the textbooks, students will be encouraged to consult extensively on the literature related to this course. Set up a certain learning group in combination with the actual situation of the students, and guide different learning groups to work together to collect data together. The content they collect can be varied, including pictures and text materials, such as all kinds of English related information and pictures, videos and so on, which are involved in daily operation and work of hotels. In this process, teachers should encourage students to use the Internet to conduct extensive data collection and collect as much information as possible about the learning content. After the collection is completed, different groups are instructed to collect and collate the collected data.

\subsection{Design situations and activities}

Designing a certain teaching situation with the related content of hotel English. In teaching, we choose to order a hotel restaurant service for the specific case of the corresponding scenario design. The teachers teaching hypothesis is restaurant where many foreign customers come for dining. Then, guide the students to think if they were the attendants of the restaurant, how should they meet customers? How to communicate with customers when ordering? How to ask the customer's needs? 


\subsection{Present scene}

In combination with the specific teaching situation, teachers can use a certain network and multimedia to present a specific learning situation to the students. In this part of the teaching, teachers can use multimedia to show some restaurant-related videos. Guide students to observe the presented restaurant environment for specific video content. At the same time, enlighten the students and guide them back to the situation of some restaurants they come into contact with in their daily lives. And guide students to think that he/ she is a an attendant there. After that, the students are instructed to combine their own daily life experience and think about what kind of communication will be between the customer and the attendant when ordering food in the restaurant. What are the questions that customers often ask when communicating? What are the common politeness terms When an attendant answers a customer's question. And then considering the teaching content, if you encountered foreign customers in the restaurant, how do you communicate with them in English to provide the necessary services?

\subsection{The development of learning activities}

In this teaching environment, we can carry out specific learning activities in combination with the actual situation. In this session, we can instruct students to complete certain learning tasks quickly through cooperation or independent study and thinking training. In the specific learning process, we can guide students to analyze and think about the situation that foreign guests come to eat, summarize what language, vocabulary and related sentence patterns may be used in the specific communication process. After the students are familiar with all kinds of commonly used communication patterns, the students are grouped reasonably. In different groups, students are encouraged to perform role plays in certain scenarios, acting as restaurant attendants or foreign clients respectively. And then perform and practice the scene of ordering. The students experience the application of all kinds of English vocabulary and sentence patterns in the performance. Finally, after independent study or group study, teachers lead students to discuss and analyze together. Analyzing various issues and summing up what are the common polite terms when attendants communicating with foreign customers in the restaurant. How to answer the names of some dishes. And how to answer the customer's questions and introduce the appropriate dishes and restaurant services. Finally, they finish the learning task.

\subsection{The teaching effect and summary}

In teaching, teachers can design specific, real and vivid teaching scenarios around teaching contents with the help of actual situations, certain networks and media. Thus effectively stimulating students 'enthusiasm for learning, enhancing their interest and curiosity about the contents of the teaching materials they are about to learn. And also paying more attention to the improvement of students' abilities. Situational teaching mode can improve teaching efficiency and effectiveness, and help students develop various abilities, such as how to quickly use the Internet to search and collect data. In general, with the help of a certain media and network technology, the application of situational teaching method in Higher Vocational English teaching can obtain the ideal teaching effect. The classroom is vivid and fulfilling, and it has achieved the ideal teaching effect.

\subsection{The matters needing attention in the English situation teaching in Higher Vocational College with the aid of media network}

It should be noted that the situation teaching method belongs to the open vocational English teaching mode. Throughout the teaching process, teachers are required to have good control over different links in the whole teaching mode and play the role of their guides and helpers well. In this context, it is also a new and higher requirement for English teachers. Therefore, in the process of Higher Vocational English teaching, in order to better implement situational teaching method, teachers also need to proceed from their own and make the appropriate preparations. It takes a long time to collect data, to teach in the classroom, to communicate with students and teachers, and to summarize and evaluate different sessions. Therefore, in order to minimize the burden of students and teachers and avoid wasting time, we need to arrange teaching time reasonably, so as to improve learning efficiency. In addition, in the use of situational teaching method, we should also pay attention to some problems that are easy to appear. For example, sometimes there are too many 
material scenarios and material information is too complicated. The lack of meaning, structural imbalance and the desalination of the crucial teaching point affect the teaching progress. The form of situational teaching is very novel and lively, but the effect is not necessarily ideal etc.

\section{Conclusion}

In a word, English is a very important discipline in the teaching system of higher vocational education, which is very important to the future career development of students. Therefore, it is very essential to actively explore new and efficient teaching methods so as to improve the level of English Teaching in higher vocational colleges. The situation teaching method lively and vivid. It can create atmosphere and artistic conception and arouse the students' enthusiasm for learning. It is a new teaching method which has attracted much attention. In this study, we try to apply the situational teaching method in Higher Vocational English teaching with the help of various media and network. It is found in practice that establishing a certain framework of situation teaching in accordance with concrete teaching content and the use of the framework can achieve the ideal effect in Higher Vocational English teaching. And the application effect of situational teaching method in Higher Vocational English teaching is confirmed. The emergence of situational teaching method came into being with the change of teaching concepts and teaching experience. It plays an important role in teaching practice, and is being paid more and more attention by teaching staff, and its application is more and more extensive.

\section{Reference}

[1] Chen Rui. Practice and Exploration of Situational Teaching in Vocational English Writing Course[J]. English on Campus(Middle),2016,(10):100-101.

[2] Zhu Youxiu, Ding Jingjing. Application of Information Technology in Vocational English Situational Teaching[J]. Science and Technology Innovation Herald,2017,(12):211,213.

[3] Shao Yan. The Practice of English Situational Teaching in Higher Vocational Colleges[J]. Vocational \& Technical Education Forum,2016,(20):79-82.

[4] Xu Yao. Exploration and Application of Vocational English Teaching for Nursing Students[J].English on Campus(Middle),2016,(10):97-98.

[5] Wang Xuelian. Application of Situational Teaching Method in English Teaching in Vocational Colleges[J].Yangtze River Series,2017,(31):88.

[6] Ding Wei. Research on Teaching Reform Strategy of English Hotel in Higher Vocational Colleges[J]. Journal of Seeking Knowledge Guide,2015,(10):69-70.

[7] Wu Yan. Application of Situational Teaching Method in English Teaching in Vocational Colleges[J]. Guide to Business,2015,(23):105-106.

[8] Li Jing. The Application of Situational Teaching Method in Vocational English Teaching[J]. Academy,2015,(22):51-52. 